\title{
The Relationship Of Improving Intrinsic Motivation On Turnover Intention By Using Job Crafting Workshop for Employee At Division $X$ in a food company
}

\section{Rahmadia Trisia Effendi ${ }^{\mathrm{a}}$ and Arum Etikariena ${ }^{\mathrm{b}}$}

${ }^{a}$ Faculty of Psychology, Universitas Indonesia, Depok, Indonesia; ${ }^{b}$ Department of Industrial and Organizational Psychology, Faculty of Psychology, Universitas Indonesia, Depok, Indonesia

*Corresponding author:

Arum Etikariena

Industrial and Organizational Psychology Department

Faculty of Psychology, Universitas Indonesia

Jl. Lkr. Kampus Raya, Depok, Jawa Barat

Indonesia, 16424

Tel.: +62 217270004

Email: arum.etikariena@ui.ac.id 


\title{
The relationship of improving intrinsic motivation on turnover intention by using job crafting workshop for employee at Division $\mathrm{X}$ in a food company
}

\begin{abstract}
This study aims to determine the relationship between intrinsic motivation and turnover intervention on employees in Division $\mathrm{X}$ at a food company as well as an appropriate intervention program to improve employee's intrinsic motivation. The study was conducted on 103 employees. Turnover intention is measured using the turnover intention questionnaire and intrinsic motivation is measured using interest/enjoyment subscale on intrinsic motivation inventory. The results showed that intrinsic motivation was significantly correlated with the turnover intention $(\mathrm{r}=-.51, \mathrm{p}<.01)$. Based on these results, the appropriate intervention design to improve intrinsic motivation is job crafting that would be provided through workshop program. The results of intervention program design evaluation by HR teams indicated that the intervention program was appropriate to be implemented in the organization.
\end{abstract}

Keywords: turnover intention, intrinsic motivation, job crafting

\section{Introduction}

Human Resources (HR) is the most important and essential resource that determines the success of the organization in managing its business. HR practitioners and managers need to understand organizational behavior to determine the form of an effective HR management strategy. One of the organizational behaviors that need to be understood is withdrawal behavior, which is one form of organizational behavior that potentially decreases organizational effectiveness (Griffin \& Moorhead, 2014). Employee behavior that seeks to separate from the organization can disrupt the stability of the organization's performance. According to Pfeffer and Sutton (2006) employee turnover is considered a major problem faced by managers in the organization (Dysvik\&Kuvaas, 2010).

Rahman and Nas (2013) define turnover as the movement of employees out of the organization permanently. A high turnover rate is an issue for the organization. It leads to increased recruitment costs, increased training needs, loss of experienced employees, and ultimately will impact on the company's financial performance (Addae, et al., 2006; Collins \& Smith, 2006; Ghosh et al., 2013; Reiche 2008). Furthermore, a high turnover also leads to disrupted organizational relationships (Ghosh et al., 2013), and disrupts the quality, consistency, and stability of the services to clients and consumers (Trevor \& Nyberg, 2008). A meta-analysis study by Griffeth, Hom, and Gartner (2000) proved that turnover intention is the strongest predictors of actual turnover. Turnover intention is the strength of employee intention to voluntary terminate employment contracts and leave the current organization to seriously search for another job opportunities after employees have been in their position for a time (Lee, Hung, and Chen, 2012).

High turnover rate problem was found in one of the multinational pharmaceutical companies in Indonesia, namely Division $X$ in a food company. The number of outgoing employees from Division X had increased from 2015 to 2016. Based on the number of retiring employees from the HR Division, the number of voluntarily resigned employees in 2015 was 21 people, while in 2016 it rose to 34 people or equivalent to $14.29 \%$. This percentage is high compared to other pharmaceutical companies. Based 
on the results of Mercer turnover survey in 2015 in consumer goods, energy, and life sciences industry, the average percentage of voluntary turnover in Asia in the consumer goods industry ranged from $12-13 \%$ and in the life sciences industry ranged from $7-8 \%$ (Elkjaer\&Filmer, 2015).

Factors influencing turnover intentions can be seen from two perspectives. External factors affecting employees to quit or stay in the organization include rewards, salary/wages, workload, work location, leadership style (Kumar \&Govindarajo, 2014), career opportunities, and also training and development opportunities (Rahman\&Nas, 2013). Internal factors affecting employees to quit or to remain in the organization are job satisfaction, perceived organizational support and perceived supervisor support (Newmann et al., 2011; Madden et al., 2015; Tuzun\&Kalemci, 2012). Other factors also include organizational commitment (Addaeet al., 2006; Gatling et al., 2016), and intrinsic motivation (Cho \& Perry, 2012; Dysvik\&Kuvass, 2010; Galletta et al., 2013; Mobley et al., 1978). From all these factors, this study would focus on intrinsic motivation variable.

Motivation is an important aspect of studying human psychological functions. Motivation concerns energy, direction, and persistence, which is an aspect of activation and intention of a behavior (Ryan \& Deci, 2000). Intrinsic motivation at work is one of the factors within the individual that influences the employee's propensity to stay or leave the organization. The study of Kuvaas (2006) and Vansteenkiste et al. (2007) suggest that intrinsic motivation is negatively correlated with turnover intentions.

This research focus was based on the phenomenon in Division X in this food company that showed low intrinsic motivation in employees. Quite many employees were seen not enjoying their work, were not excited when needed, and were working just to avoid punishment. Loss of interest and enjoyment at work indicates decreasing intrinsic motivation in employees. An intrinsically motivated individual is encouraged to perform a task because he/she finds interest and enjoyment in performing his tasks, and not because of external motives, pressure, or reward (Ryan \& Deci, 2000). From the problems in the organization and the results of previous studies, the researcher hypothesized that:

Ha: There is a negative relationship between intrinsic motivation and turnover intentions on employees in Division $\mathrm{X}$ in a food company.

In addition to confirming the relationship between intrinsic motivation and turnover intentions, this study also tries to identify appropriate interventions in helping to solve employee turnover intention problems in Division X. Interventions at this study focused on increasing intrinsic motivation on employees. One of the strategies for improving intrinsic motivation is through job design (Griffin \& Moorhead, 2014; Luthans, 2011; Robbins \& Judge, 2015). Job design can occur top-down, i.e., done by organizations and managers, and bottom-up, i.e., employees (holder of office) proactively design their work (Berg, Wrzesniewki, \& Dutton, 2010).

Individuals can design work independently through job crafting. Job crafting is a new approach that can be considered as an alternative to doing job design (Oldham \& Hackman, 2010). This approach is appropriate according to organizational conditions in the $21^{\text {st }}$ century. Currently, changes in job content should not always wait for initiatives 
from managers but can be initiated by employees (Oldham \& Hackman, 2010). Some companies have been practicing job crafting on employees, including Google, Logitech, and VMware (Vivian, 2016). Job crafting also provides positive results, such as happiness at work, raises the positive meaning of work, improves employee engagement, organizational commitment, and work performance (Wrzesniewski, LoBuglio, Dutton, \& Berg, 2013).

Job crafting is a physical and cognitive change in task boundaries and relationships (relational boundaries) in the work of the individual (Wrzesniewski\& Dutton, 2001). Physical change refers to changes in the shape, scope, and number of tasks that individuals perform, whereas cognitive change refers to changes in how individuals perceive their work. Changing the boundaries of relations means a change in the interaction of the individual with others as he/she performs his duties (Wrzesniewski\& Dutton, 2001; Berg et al., 2010).

Berg, Dutton, and Wrzesniewski (2013) suggested that job crafting is an employee process in defining (redesigning) and reimagining their work in a more meaningful way (p. 82). Changes at work can affect the meaningfulness of a job (Berg et al., 2013) and meaningfulness can improve motivation, job satisfaction, and performance (Grant, 2007; Hackman \& Oldham, 1976; Rosso, et al., 2010). Job crafting, which was done with the alteration between the work with the employee's primary motives or with specific results that encourage them to give more effort and persistence (e.g., pleasure or comfort at working, self-development), can create meaningfulness for themselves (Berg et al., 2013). Also, job crafting experience increased the sense of responsibility, achievement motivation, and a sense of ability in performing tasks. It positively influences intrinsic motivation at work (Lyons, 2008).

The relationship between job crafting and intrinsic motivation is further explained by the self-determination theory (SDT) by Ryan and Deci (2000). SDT assumes that individuals have an innate tendency toward personal growth and basic psychological needs, such as the need to act autonomously and control their behavior (need for autonomy), feel the ability to perform the task (feel competence), and the need to connect with others (relatedness). Job crafting can be a way to fulfill these three basic needs when individuals make changes to the restrictions that exist in their work.

\section{Methods}

\section{Participant}

This study is conducted on employees who work in Division X. The respondents were permanent employees that already have one year tenure, with varying positions such as staff, supervisors, associate manager, and manager. Respondents were chosen by using simple random sampling. An online survey link were sent to the e-mail address of each selected respondent.The respondents of this research were 144 employees, but at the end of the study, only 108 respondents gave their response (response rate $75 \%$ ) and the data that could be processed is from 103 respondents. Data showed that most respondents are male $(64.1 \%)$ and worked as a staff $(88.3 \%)$. Based on age range, most respondents were in the age range 31-40 years (59.2\%), whereas most respondents had 6-10 years tenure $(26.2 \%)$. 


\section{Research Design}

This research is a correlational study. The variables studied were the turnover intention (dependent variable) and intrinsic motivation (independent variable). Both variables are correlated to determine the relationship between the two variables.

\section{Measures}

a. Turnover Intention Questionnaire

The turnover intention questionnaire used in this research was the adaptation of the turnover intention questionnaire (Lee et al., 2012). In this questionnaire, there are ten items and the response format in the form of Likert scale 5 points, which is very agreed, agree, neutral, disagree, and strongly disagree. The turnover intention questionnaire is relatively reliable in measuring turnover intentions, with an alpha coefficient $(\alpha)=.83$.

b. Intrinsic Motivation Inventory: enjoyment/interest subscale

The intrinsic motivation measurements in this study used the enjoyment/interest subscale on Intrinsic Motivation Inventory developed by Ryan (1982). The questionnaire consists of seven items and the response format in the form of Likert scale 5 points, which strongly agree, agree, neutral, disagree, and strongly disagree. The intrinsic motivation questionnaire is relatively reliable in measuring intrinsic motivation, with an alpha coefficient $(\alpha)=.89$.

\section{Data Analysis}

The method used to analyze data are frequency distribution, Pearson product moment correlation, and linear regression.

\section{Results}

From all the data have been collected, it was found that there is a negative correlation between intrinsic motivation to turnover intention $(\mathrm{r}=-.51, p<.01)$. It means that if intrinsic motivation is high, the turnover intention would be low, and vice versa. This result supported the hypothesis in this study.

The data also showed43 respondents $(41.75 \%)$ have the low intrinsic motivation, and 60 respondents $(58.25 \%)$ have high intrinsic motivation. For turnover intention, 48 respondents $(41.75 \%)$ have the low turnover intention, and 55 respondents $(53.40 \%)$ have high turnover intention. Based on the results of a linear regression test, intrinsic motivation was found to significantly affect the intention of turnover. Intrinsic motivation has a proportion of influence on turnover intention of $29 \%\left(R^{2}=29, p<.01\right)$, while the remaining $71 \%$ is influenced by other variables. It means that variations in turnover intention are also influenced by other variables which not included in this study.

Based on the results of this study, the appropriate intervention program to increase intrinsic motivation is a job crafting workshop. The characteristics of participants are staff level, has the high turnover intention and low intrinsic motivation. Intervention in this study is planned to last for six weeks, as follows: 
Tabel 1.

Intervention Implementation Plan

\begin{tabular}{lllllll}
\hline \multirow{2}{*}{ Activities } & \multicolumn{5}{c}{ Time (weeks) } \\
\cline { 2 - 7 } & 1 & $\mathbf{2}$ & $\mathbf{3}$ & $\mathbf{4}$ & $\mathbf{5}$ & $\mathbf{6}$ \\
\hline Job crafting workshop & $X$ & & & & & \\
Job crafting action at daily work & & $X$ & $X$ & $X$ & $X$ & $X$ \\
Reflection meeting & & & & & & $X$ \\
\hline
\end{tabular}

After participated in job crafting workshop, participants were asked to undertake an action plan that they had prepared over the next four weeks. Furthermore, a reflection meeting was attended by participants and their managers. The time required in this activity ranges from 30 to 45 minutes. The topic discussed in the reflection meeting is the participants' experience in implementing job crafting in the actual work environment, perceived barriers, how to overcome obstacles, and also positive impacts and negative impacts of job crafting.

\section{Discussion}

According to statistical analysis, there is a significant negative correlation between intrinsic motivation and turnover intention, which confirms hypothesis in this research. The analysis supports the theory posited for turnover intention. Turnover intention is negatively correlated with intrinsic motivation (Kuvaas, 2006; Vansteenkiste et al., 2007). Employees have a lower tendency to leave organizations that contribute to the fulfillment of their psychological needs, such as the need for autonomy, feel the ability to perform the task (feel competence), and need to relate to others (relatedness) (Vansteenkiste et al., 2007). Thus, employees who are intrinsically motivated in work have a small tendency to leave their organization.

A significant relationship between intrinsic motivation and turnover intention makes intrinsic motivation to be one of the predictors of turnover intention. Cultivating intrinsic motivation is an enduring process that decreases turnover intention of employees. This study proposed job crafting intervention to enhances intrinsic motivation.

In this study, job crafting interventions are provided through workshop to improve employee's knowledge and skills on how to redesign their tasks that fit to their personal needs and characteristics, such as work motives, strengths, and passion. However, actual workshop activities could not be implemented directly due to some conditions in the organization. So, the effectiveness of intervention programs in improving employee intrinsic motivation is still unknown.

To determine the extent to which interventions can be applied, HR team evaluated the intervention design. Based on the evaluation, job crafting workshop intervention is considered to align and support some existing programs in the organization, such as initiating proactive behavior of employees in personal development, stimulating innovation at work, and can be used as a method of updating existing job description. HR suggested to include managers in job crafting workshop. Manager's involvement is considered important in job crafting process, so job crafting aligns with organization strategy. Also, the involvement of managers in job crafting undertaken by subordinates can improve the dialogue or communication between managers and subordinates. 
Managers who are actively involved in job crafting processes give more benefits, both to individuals and organizations. It also minimized the potential risks of job crafting (Schoberova, 2015). According to Schoberova (2015), there are several roles of managers in job crafting. They include to prevent misalignmentwith the goals of team and organizationduring tasks adjustments performed by subordinates, to inform subordinates about job crafting strategies and stimulate them to take the initiative to do job crafting, amd to communicate organizational goals to subordinates clearly to avoid dysfunctional job crafting. Discussion and cooperation with managers in modifying tasks make job crafting more effective and support the achievement of individual, team and organizational performance.

For further research, researchers should interview with respondents who have a high turnover intention and low intrinsic motivation to get a comprehensive description of the relationship dynamics between turnover intention and intrinsic motivation. Also, researchers are expected to implement the intervention design so the effectiveness of this intervention in enhancing intrinsic motivation could be measured. The workshop should also emphasize the role of managers and the benefits of managerial involvement in job crafting. Managers can discuss job crafting into coaching activities with subordinates so they can monitor the progress of action plan implementation prepared by employees and provide feedback based on the progress. Managers are involved in providing corrections and guidance to subordinates if task adjustments made by subordinates are irrelevant to the team and organizational goals or the achievement of the team targets. When job crafting brings positive results for employees, managers can encourage employees to make job crafting as part of their development plan.

\section{References}

Abbasi, S. M., \& Hollman, K. W. (2000). Turnover: The real bottom line. Public Personnel Management, 29(3), 333342.

Addae, H. M., Praveen, P.K., \& Davis, E.E. (2006). Organizational commitment and intentions to quit: An examination of the moderating effects of psychological contract breach in Trinidad and Tobago. International journal of organizational analysis, 14(3), 225-238.

Berg, J.M., Wrzesniewski, A., \& Dutton, J.E. (2010). Perceiving and responding to challenges in job crafting at different ranks: When proactivity requires adaptivity. Journal of Organizational Behavior, 31, 158-186.

Berg, J. M., Dutton, J. E., \&Wrzesniewski, A. (2013). Job crafting and meaningful work. In B. J. Dik, Z. S. Byrne \& M. F. Steger (Eds.), Purpose and meaning in the workplace (pp. 81-104). Washington, DC: American Psychological Association.

Cho, Y.J. \& James, L.P. (2012). Intrinsic motivation and employee attitudes: Role of managerial trusworthiness, goal directedness, and extrinsic reward expectancy. Review of Public Administration, 32(4), 382 - 406

Cozbi, P.C., \& Bates, S.C. (2011). Methods in behavioral research $\left(11^{\text {thed }}\right)$. USA: McGraw Hill

Cummings, T.G. \& Worley, C.G. (2015). Organizational development \& change. Australia: South-Western/Cengage Learning

Deci, E.L., Connell, J.P. \& Ryan, R.M. (1989). Self-determination in a work organization, Journal of Applied Psychology, 74(4), 580-90.

Deci, E.L. \& Ryan, R.M. (2000), The 'what' and 'why' of goal pursuits: human needs and the self-determination of behavior, Psychological Inquiry, 11(4), 227-68.

Demerouti, E. (2014). Design your own job through job crafting. European Psychologist, 19(4), 237-247

Dysvik, A., \&Kuvaas, B. (2010). Exploring the relative and combined influence of mastery-approach goals and work intrinsic motivation on employee turnover intention. Personnel review, 39(5), 622-638.

Elkjaer, D. \&Filmer, S. (2015). Trends and Driver of Workforce Turnover. Mercer. Retrieved from https://www.mercer.com/content

Gagné, M., \& Deci, E. L. (2005). Self-determination theory and work motivation. Journal of Organizational behavior, 26(4), 331-362. 
Galletta, M., Portoghese, I., \&Battistell, A. (2011). Intrinsic motivation, job autonomy and turnover intention in the italian healthcare: The mediating role of affective commitment." Journal of Management Research, 3(2), E7

Gatling, A., Kang, H. J. A., \& Kim, J. S. (2016). The effects of authentic leadership and organizational commitment on turnover intention. Leadership \& Organization Development Journal, 37(2), 181-199.

Ghosh, P., et al. (2013). Who stays with you? Factors predicting employee's intention to stay. International Journal of Organizational Analysis, 21(3), 288-312

Grant, A. M. (2007). Relational job design and the motivation to make a prosocial difference. Academy of Management Review, 32(2), 393-417.

Gravetter, F. J., \&Forzano, L-A. B. (2012). Research methods for the behavioral sciences $\left(4^{\text {th }} \mathrm{ed}\right)$. USA: Cengage Learning

Griffeth, R.W., Hom, P.W., \&Gaertner, S. (2000). A meta-analysis of antecedents and correlates of employee turnover: update, moderator tests, and research implications for the next millennium, Journal of Management, $26,463-88$

Griffin, R.W. \&Moorhead,G. (2014). Organizational behavior: Managing people and organizations (1 ${ }^{\text {thed). USA: }}$ Cengage Learning

Hackman, J. R., \& Oldham, G. R. (1976). Motivation through the design of work: Test of a theory. Organizational Behavior \& Human Performance, 16(2), 250-279.

Hakanen, J. J., Schaufeli, W. B., \&Ahola, K. (2008). The Job Demands-Resources model: A three-year cross-lagged study of burnout, depression, commitment, and work engagement. Work \& Stress, 22(3), 224-241.

Jeswani, S. (2016). Do intrinsic motivation influence turnover intention? Structural equation modelling approach among technical faculty members. International Journal of Business and General Managemenet, special edition November 2016, 1-20.

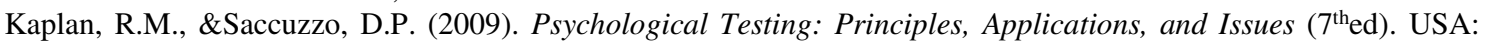
Wadsworth-Cangage Learning

Kumar, R. (2011). Research Methodology: A step by step guide for beginners. USA: Sage Publications

Kumar, M.D., \&Govindarajo, N.S. (2014). Intrument development "Intention to Stay Instrument" (ISI). Asian Social Science, 10(12). 149-169

Kuvaas, B. (2006), Performance appraisal satisfaction and employee outcomes: mediating and moderating roles of motivation, The International Journal of Human Resource Management, 17(3), 504-22.

Lee, D-C, Hung, L-M., \& Chen, M-L. (2012). Empirical study on the influence among corporate sponsorship, organizational commitmen, organizational cohesivenss and turnover intention. Journal of Management and Sustainability, 2(2), 43-53

Luthans, F. (2011). Organizational behavior: An eidence based approach. New York: McGraw-Hill/Irwin

Lyons, P. (2008). The Crafting of Jobs and Individual Differences. Journal of Business Psychology, 23, 25-36.

Madden, L., Mathias, B. D., \& Madden, T. M. (2015). In good company: The impact of perceived organizational support and positive relationships at work on turnover intentions. Management Research Review, 38(3), 242263.

Marczyk, G., DeMatteo, D., Festinger, D. (2005). Essentials of research design and methodology. New Jersey: John Wiley \& Sons

McAuley, Duncan, T., \&Tammen, V.V. (1989). Psychometric properties of the intrinsic motivation inventory in a competitive sport setting: A confirmatory factor analysis. Research Quarterly for Excercise and Sport, 60, 4858

Mobley, W.H., Horner, S.O. and Hollingsworth, A.T. (1978). An evaluation of precursors of hospital employee turnover, Journal of Applied Psychology, 63, 408-14.

Mobley, W.H. (1977). Intermediate linkages in the relationship between job satisfaction and employee turnover". Journal of Applied Psychology, Vol. 62, 237-240

Nazir, S., Shafi, A., Qun, W., Nazir, N., \& Tran, Q.D. (2016). Influence of organizational rewards on organizational commitment and turnover intentions. Employee Relations, 38(4), 596-619

Newman, A., Thanacoody, R., \& Wendy, Huy, (2011). The effects of perceived organizational support, perceived supervisor support and intra-organizational network resources on turnover intentionsA study of Chinese employees in multinational enterprises, Personnel Review,41(1), 56 - 72

Noe, R.A., Hollenbeck, J.R, Gerhart, B., \& Wright, P.M. (2011). Fundamentals of human resource management ( $4^{\text {thed}}$ ). New York: McGraw-Hill

Nunnally, J.C. \& Bernstein, I.H. (1994). Psychometric theory $\left(3^{\text {rd }}\right.$ ed). New York: McGraw-Hill

Oldham, G. R., \& Hackman, R. J. (2010). Not what it was and not what it will be: the future of job design research. Journal of Organizational Behavior, 31 (2-3), 463-479.

Omoregie, H. (2015). The 5M's of business management: organizing them effectively. Retrieved fromhttps://www.linkedin.com/pulse/5-ms-business-management-organising-them-effectively-henryomoregie

Podsakoff, P.M., MacKenzie, S.B., Lee, J.-Y. and Podsakoff, N.P. (2003). Common method biases in behavioral research: a critical review of the literature and recommended remedies, Journal of Applied Psy-chology, 88(5), 879-903.

Pulley, P.A. (2007). A research study of intrinsic and extrinsic motivation in supposition to the self-directed workers in an industrial application. A Dissertation Submitted in Partial Fulfillment of the Requirements For the Doctor of Philosophy Degree Southern Illionis University

Rahman, W. \&Nas, Z, (2013). Employee development and turnover intention: theory validation, European Journal of Training and Development, 37(6), 564 - 579 
Robbins, J.T. (2000). A study of the relationship between skill variety and high internal work motivation, task identity and high internal work motivation, task significance and high internal work motivation, autonomy and high internal work motivation, and intrinsic job feedback and high internal work motivation in the manufacturing area. A Dissertation Submitted in Partial Fulfillment of the Requirements For the Doctor of Philosophy Degree Nova Southeastern University Enterpreneurship

Robbins, S.P. \& Judge, T. (2013). Organizational behavior (15 ${ }^{\text {thed}}$ ). USA: Pearson

Robbins, S.P. \& Judge, T. (2015). Organizational behavior (16 $6^{\text {th }}$ d). USA: Pearson

Ryan, R.M. (1982). Contorl and information in the intrapersonal sphere: an extension of cognitive evaluation theory. Journal of Personality, 43(3), 450-461

Ryan, R.M., Koestner, R., \& Deci, E.L. (1991). Ego-involved persistence: when free choice behavior is not intrinsically motivated. Motivation and Emotion, 15(3), 185-205

Ryan, R.M. \& Deci, E.L. (2000). Self-determination theory and the facilitation of intrinsic motivation, social development, and well-being. American Psychologist, 55(1), 68-78.

Ryan, R.M. \& Deci, E.L. (2000). Intrinsic and extrinsic motivations: classic definitions and new directions. Contemporary Educational Psychology, 25 (1), 54-67

Schoberova, M. (2015). Job crafting and personal development in the workplace: employees and managers cocreating meaningful and productive work in personal development discussions. A Project Submitted in Partial Fulfillment of the Requirement for the Degree of Master of Applied Positive PsychologyUniversity of Pennsylvania.

Stangor, C. (2011). Research mthods for the behavioural sciences $\left(4^{\text {thed}}\right)$. USA: Wadsworth

Tims, M., \& Bakker, A. B. (2010). Job crafting: Towards a new model of individual job redesign. SA Journal of Industrial Psychology, 36(2), 1-9.

Tuzun, I. Kalemci, \&ArzuKalemci, R. (2012). Organizational and supervisory support in relation to employee turnover intentions. Journal of Managerial Psychology, 27(5), 518-534.

Vallerand, R.J. (1997). Toward a hierarchical model of intrinsic and extrinsic motivation", in Zanna, M.P. (Ed.), Advances in Experimental Social Psychology, Academic Press, New York, NY.

Vansteenkiste, M., Neyrinck, B., Niemiec, C., Soenens, B., De Witte, H., \& Van den Broeck, A. (2007). On the relations among work value orientations, psychological need satisfaction and job outcomes: a selfdetermination theory approach. Journal of Occupational and Organizational Psychology, 80 (2), 251-77.

Vivian, G. (2016). Why innovative companies like google are letting employees to craft their own jobs. Retrieved from https://www.fastcompany.com/3059345/why-innovative-companies-like-google-are-letting-employeescraft-their-own-jobs

Wrzesniewski, A., \& Dutton, J. E. (2001). Crafting a job: Revisioning employees as active crafters of their work. Academy of Management Review, 26(2), 179-201.

Wrzesniewski, A., LoBuglio, N., Dutton, J.E, \& Berg, J.M. (2013). Job crafting and cultivating positive meaning and identity in work. Positive Organizational Psychology, vol 1, 281-302. 